\title{
Toxoplasmosis seroprevalence in wild small rodents, potentially preys of ocelots in north-eastern Mexico
}

\author{
Emilio Rendón-Franco ${ }^{1}$, Lizbeth Xicoténcatl-García ${ }^{2}$, Claudia Patricia Rico-Torres ${ }^{2}$, \\ Claudia Irais Muñoz-García ${ }^{1}$, Arturo Caso-Aguilar ${ }^{3}$, Gerardo Suzán $^{4}$, Dolores Correa ${ }^{2}$, \\ and Heriberto Caballero-Ortega ${ }^{2, *}$ \\ 1 Departamento de Producción Agrícola y Animal, Universidad Autónoma Metropolitana - Unidad Xochimilco, Mexico \\ 2 Laboratorio de Inmunología Experimental, Instituto Nacional de Pediatría, Secretaría de Salud, México D.F. 04530, Mexico \\ 3 Caesar Kleberg Wildlife Research Institute, Texas A\&M University-Kingsville, 700 University Blvd., MSC 218, Kingsville, \\ TX 78363, USA \\ ${ }^{4}$ Facultad de Medicina Veterinaria y Zootecnia, Universidad Nacional Autónoma de México, México 04510, Mexico
}

Received 28 August 2014, Accepted 23 October 2014, Published online 7 November 2014

\begin{abstract}
The aim of this study was to assess the prevalence of Toxoplasma gondii infection in rodents that coexist with ocelots in north-eastern Mexico. Eighty rodents of five genera were captured and their serum samples tested for specific IgG antibodies to $T$. gondii by in-house indirect ELISA using three different conjugates. Prevalences of $7 \%$ (3/44) and 33\% (4/12) were found in Sigmodon hispidus and Liomys irroratus, respectively, and were significantly different. All Baiomys taylori and Oligoryzomys fulvescens were negative for the presence of anti-T. gondii IgG antibodies. The samples from Peromyscus spp. could not be analyzed because none of the three conjugates tested recognized their immunoglobulins. Infection was confirmed in one single specimen of L. irroratus by qPCR, which generated an estimate of 146 parasites per $\mathrm{mg}$ of muscle tissue. The results strongly support the notion of active T. gondii transmission between rodents and felines in this zone of Mexico and an important role of some rodent species in the sylvatic cycle of $T$. gondii.
\end{abstract}

Key words: Toxoplasma gondii, Rodents, Seroprevalence, Molecular diagnosis, Mexico.

Résumé - Prévalence de la toxoplasmose chez les petits rongeurs sauvages, proies potentielles des ocelots au nord-est du Mexique. Le but de cette étude était d'estimer la prévalence de l'infection par Toxoplasma gondii chez les rongeurs qui coexistent avec des ocelots dans le nord-est du Mexique. Quatre-vingts rongeurs appartenant à cinq genres différents ont été capturés et les anticorps IgG spécifiques anti-T. gondii ont été recherchés dans leurs sera par une méthode ELISA indirecte développée dans le laboratoire, utilisant trois conjugués différents. Des prévalences de $7 \%(3 / 44)$ et $33 \%(4 / 12)$ ont été trouvées respectivement chez les espèces Sigmodon hispidus et Liomys irroratus, cette différence étant statistiquement significative. La recherche d'anticorps IgG anti- $T$. gondii a été négative chez tous les Baiomys taylori et Oligoryzomys fulvescens. Les sera des Peromyscus spp. n'ont pas été analysés car aucun des trois conjugués testés n'a reconnu leurs immunoglobulines. L'infection a été confirmée par qPCR chez un spécimen de L. irroratus avec une quantité de 146 parasites par $\mathrm{mg}$ de tissu musculaire. Ces résultats suggèrent fortement une transmission active de $T$. gondii entre rongeurs et félidés dans cette zone du Mexique et un rôle important de certaines espèces de rongeurs dans le cycle selvatique de T. gondii.

\section{Introduction}

Toxoplasma gondii is an obligate intracellular parasite capable of infecting all warm-blooded animals including rodents, which are common intermediate hosts. Its definitive

\footnotetext{
*Corresponding author: hcaballero_2000@yahoo.com.mx
}

hosts are all members of the Felidae family, including the domestic cat (Felis catus) so there are domestic, synanthropic, and wildlife cycles [12]. Parasite dynamics are well understood in domestic animals and in humans, but little is known about the wild cycle [22]. The gaps in this knowledge are important in view of the increasing interaction between wildlife and 
urban populations and the risks for species conservation and public health.

Predation is a fundamental aspect of $T$. gondii transmission; consequently rodents are important sources of infection for domestic, feral, and wild cats. These small mammals compose two-thirds of the diet of wild small and medium felids, although this proportion may vary depending on several factors, including season, rodent density, felid species, and the presence of other prey [19].

Ocelots are medium-sized felids with a diet that mainly consists of vertebrates smaller than $1000 \mathrm{~g}$ [20]. In Mexico, De Villa et al. (2002) showed that rodents were the main components of their diet, Liomys pictus being the most frequent [9]. Although some authors have highlighted the theoretical role of rodents in the maintenance of $T$. gondii in wildlife, there are few reports of prevalence and distribution of this protozoan in wild felids [2]. A previous study in Soto La Marina, Tamaulipas, Mexico, demonstrated a prevalence of $69 \%$ of T. gondii infection in ocelots [21]. Although it is clear that these wild cats play an important role in the Toxoplasma wildlife cycle of this region, toxoplasmosis prevalence in the prey populations where these cats are the only possible definitive hosts is not known. In this study, we describe the prevalence of $T$. gondii infection using direct and indirect ELISA tests, as well as the parasite load estimated by qPCR, in rodents that coexist with ocelots in north-eastern Mexico.

\section{Material and methods}

\section{Bioethics}

Animals were trapped with authorization from the Mexican Ministry of Environment and Natural Resources (SEMARNAT), Registration No. FAUT-0250. The jurisdiction gives authorization to capture wild species for research purposes, provided the procedures do not cause harm.

\section{Rodent trapping}

The study was performed at Los Ebanos ranch, located in Soto La Marina, Tamaulipas, Mexico, $\left(24^{\circ} 30^{\prime}\right.$ to $23^{\circ} 17^{\prime} \mathrm{N}$ and $-98^{\circ} 31^{\prime}$ to $-97^{\circ} 44^{\prime} \mathrm{W}$ ) during September 2008. The predominant natural vegetation is tropical sub-deciduous forest, but pastures for livestock grazing exist as well. The area is on the coast of Tamaulipas, at $10 \mathrm{~m}$ above sea level. The weather at Soto La Marina is warm-moist, where temperature and rainfall ranges are $20-26{ }^{\circ} \mathrm{C}$ and $700-1100 \mathrm{~mm}$, appropriate conditions for $T$. gondii transmission [16]. The study area was selected because two wildcat species have previously been recorded, jaguarundi (Puma yagouaoroundi) and ocelot (Leopardus pardalis), and a high prevalence of T. gondii infection was previously reported in the second species $[5,21]$.

All rodents trapped were included in the sampling protocol. They were captured using Sherman ${ }^{\circledR}$ live traps (model 3310G, $10 \times 3 \times 3$ inches, Tomahawk Live Trap Company, Tomahawk, Wisconsin, USA) baited with a mixture of peanut butter and oats. Quadrants $\left(3600 \mathrm{~m}^{2}\right)$ were established with 49 traps in each (in patterns of $7 \times 7,10 \mathrm{~m}$ apart from each other). The distance between the quadrants was around $500 \mathrm{~m}$. Traps were set in a maximum of three quadrants (=147 traps/night) for two nights (total of 294 traps examined) up to complete nine quadrants (=882 traps). Each rodent trapped was handled according to the American Society of Mammalogists recommendations and identified using standard field guides [14]. A list of wild rodent species of the Tamaulipas State was created from the literature [17]. With this list and field guides, an identification key based on morphologic characteristics was developed and used in the field [14]. Body measurements were used for identification of each animal. The rodents were then bled by retro-orbital sinus puncture, and observed for at least 30 minutes (min) to check they were alert and responsive before releasing them. Blood samples were collected and centrifuged to obtain between 50 and $100 \mu \mathrm{L}$ serum, which was aliquoted and frozen at $-20{ }^{\circ} \mathrm{C}$ until tested. One Liomys irroratus specimen (Li62) died during manipulation, so samples from brain, lungs, skeletal muscles, liver, and kidney were collected and preserved for qPCR.

\section{Selection of conjugate by direct ELISA}

Since there are no specific conjugates to detect immunoglobulins of wild rodents, three different conjugates coupled to peroxidase were tested by direct ELISA: Protein A (from Staphylococcus aureus), Protein G (from Streptococcus pyogenes), and anti-mouse IgG. A mixture of both proteins $(\mathrm{PA}+\mathrm{PG})$ was also tested. Polystyrene plates (Maxisorp Nunc, New York, USA) were sensitized with $100 \mu \mathrm{L} /$ well of serum sample of each captured rodent from different genus, diluted 1:100 in $0.015 \mathrm{M}$ carbonate buffer, $\mathrm{pH} 9.6$ at $4{ }^{\circ} \mathrm{C}$ overnight. Plates were washed 5 times with $200 \mu \mathrm{L} /$ well of $0.01 \mathrm{M}$ phosphate buffered saline (PBS) with $0.05 \%$ Tween 20 (PBS-T) in an automated washer (BIO-RAD ImmunoWash 1575; Hercules, California, USA). Subsequently, $100 \mu \mathrm{L} /$ well of Protein A (1:250), Protein G (1:250), a mixture PA + PG $(1: 250)$ or anti-mouse $\operatorname{IgG} \gamma$ chain specific $(1: 1000)$ developed in goat (Sigma-Aldrich Corp., St Louis, MO, USA, products P8170, P8651, and A3673, respectively) were added and incubated at $37{ }^{\circ} \mathrm{C}$ for $2 \mathrm{~h}$. IgG was detected with $100 \mu \mathrm{L}$ of a chromogen-substrate solution buffered with $0.1 \mathrm{M}$ citrate ( $5 \mathrm{~mL}$ citric acid, $5 \mathrm{~mL}$ sodium citrate, $5 \mathrm{mg}$ O-phenylenediamine-Sigma-Aldrich Life Science, St. Louis, MO, USA and $4.5 \mu \mathrm{L} \mathrm{30 \%} \mathrm{hydrogen} \mathrm{peroxide).} \mathrm{The} \mathrm{reaction} \mathrm{was} \mathrm{stopped}$ with $50 \mu \mathrm{L} /$ well $1 \mathrm{~N}$ sulphuric acid and absorbance values were measured at $490 \mathrm{~nm}$ in a Turner Biosystems 9300-010 Modulus Microplate Multimode Reader (CA, USA), using the Microplate Reader Modulus ${ }^{\mathrm{TM}}$ software (Turner Biosystems, CA, USA).

\section{Detection of anti-T. gondii antibodies by indirect ELISA}

Immunoassays were performed as previously standardized and taking into account the direct ELISA results [24]. Plates were coated with $100 \mu \mathrm{L} /$ well of $T$. gondii crude extract from RH strain tachyzoites $(2 \mu \mathrm{g} / \mathrm{mL})$ in carbonate buffer at $4{ }^{\circ} \mathrm{C}$ overnight and washed as described above; next, non-specific 
binding sites were blocked with $200 \mu \mathrm{L}$ of $1 \%$ bovine serum albumin (Euro-Clone, Milan, Italy, product JI001000173) for $30 \mathrm{~min}$ at $37^{\circ} \mathrm{C}$. Wells were washed and $100 \mu \mathrm{L}$ of each serum sample, diluted 1:100, were added and incubated for $2 \mathrm{~h}$ at $37^{\circ} \mathrm{C}$. One hundred $\mu \mathrm{L} /$ well of Protein A (SigmaAldrich Corp.) diluted 1:250 were added and incubated at $37^{\circ} \mathrm{C}$ for $2 \mathrm{~h}$. After performing the appropriate washes, the antigen-antibody complexes were revealed and read as described above for direct ELISAs.

Because there were no wild rodent positive or negative control sera for detection of $T$. gondii infection, the cut-off point was calculated using the frequency distribution of the absorbance values, which had normal distribution, using their average plus 3 times the standard deviation, as previously described [23].

\section{Molecular diagnosis}

Toxoplasma gondii DNA was detected using qPCR on the organs of one rodent of a single specimen of L. irroratus (Li62), which died during sampling. The parasite load was calculated in skeletal muscle using $B 1$ gene as a target, according to a previous report [6].

\section{Statistical analysis}

Prevalences with $95 \%$ confidence intervals were calculated and the significance of differences among species was determined using Chi-square or Fisher's exact tests, using Epidat $3.1^{\circledR}$ software (Servicio de Epidemiología; Dirección Xeral de Innovación e Xestión de Saúde Pública, Santiago de Compostela, Coruña, Spain). Confirmation of the normal distribution of low absorbance values was determined by Shapiro-Wilk and Jarque-Bera tests.

\section{Results}

Eighty rodents of five genera were captured and sampled: Baiomys taylori $(n=2)$, Oligoryzomys fulvescens $(n=2)$, Sigmodon hispidus $(n=44)$, Liomys irroratus $(n=12)$, and Peromyscus spp $(n=20)$. Figure 1A shows that, with the exception of $S$. hispidus, the Protein A conjugate detected immunoglobulins (Igs) in all rodents efficiently. Samples from Peromyscus spp could not be analyzed because none of Protein A, Protein G nor anti-mouse IgG conjugates adequately recognized their Igs.

Normal distribution in low absorbance samples was demonstrated $(P=0.421$ and $P=0.486$ by Shapiro-Wilk and Jarque-Bera tests, respectively) and a cut-off point could be established. Few positive samples can be clearly seen at the right of this cut-off point (Figure 1B). The estimated prevalence of $T$. gondii was $6.8 \%(n=44$, CI 95\% $1.43-$ $18.66)$ and $33.3 \%(n=12$, CI 95\% 9.93-65.11) for $S$. hispidus and L. irroratus, respectively; these values were significantly different $\left(\chi^{2}=6.06, P=0.013\right)$.

The DNA from $T$. gondii was detected in three (brain, skeletal muscles, and lungs) of five tissues of the L. irroratus specimen examined by qPCR. Due to the amount of available tissue and the quality of DNA extracted, quantification of the parasite load could only be performed in skeletal muscle. A mean load of 146 parasites per $\mathrm{mg}$ in this tissue was calculated; the correlation coefficient and E-value of the standard curve were 0.98 and $93.8 \%$ respectively, which reflected a very good linearity and high efficiency. Assuming that the parasite is homogeneously distributed, it is estimated that the rodent (about $48 \mathrm{~g}$ ) may contain about $7 \times 10^{6}$ parasites.

\section{Discussion}

Microorganisms that cause zoonotic diseases, including those that are able to transit from wildlife to humans have public health implications. This is the case with $T$. gondii, which is common in domestic and wild animals [12]. Little is known, however, about the epidemiology of $T$. gondii in wildlife in Mexico. Dubey et al. (2009) demonstrated low seroprevalences of $T$. gondii in mice and rats (3.1\% and $0.8 \%$, respectively) and no seropositive terrestrial squirrels (Spermophilus variegates) from Durango in western Mexico [13]. Besides this, there are no studies on $T$. gondii prevalence in wild or synanthropic rodent species in Mexico. Here, we report the frequency of anti- $T$. gondii antibodies in wild rodents from Tamaulipas, in eastern Mexico. Since rodents are among the most species-rich groups, it is impractical to have specific conjugates for each genus or species. Thus, in this study an immunoassay to detect anti- $T$. gondii antibodies in different species of rodents was developed, using as conjugate protein A coupled to peroxidase [1]. It was adequate for all species tested except for Peromyscus spp. Thus, the prevalence of T. gondii in this rodent species could not be determined.

Prevalence of anti- $T$. gondii antibodies in S. hispidus was approximately $7 \%$, which is among the lowest values reported in the literature $[3,7]$. This host species is widely distributed and lives in quite diverse habitats. Therefore, it is likely that the large variation in the prevalence reported for this species could be due to environmental variations [4]. Although the role of L. irroratus in the epidemiology of $T$. gondii in wildlife in the area studied was suspected, the detection of antibodies reported here is the first record of the infection in these rodents, which are common preys of ocelots and was found in $62.7 \%$ of feline feces in Jalisco, Mexico [9]. It would be interesting to study the dynamics of $T$. gondii at different times of year in wild rodents, because a seasonal pattern of increase in transmission in autumn and winter and lower in spring and summer has been postulated. This seasonal increase in the proportion of infected rodents might lead to an increase in the risk of infection for felines [15].

Significant differences in $T$. gondii prevalence were observed between the two species of rodents that could be evaluated; this has been observed before both for wild and domestic hosts [18]. Ecological characteristics such as diet and longevity may explain these observations, as suggested by De Thoisy et al. (2003) [8]. Nevertheless, other authors have detected differences among rodent species, but no specific factors have been related to this variation [7]. Differences in the microhabitat should also be considered, since L. irroratus 

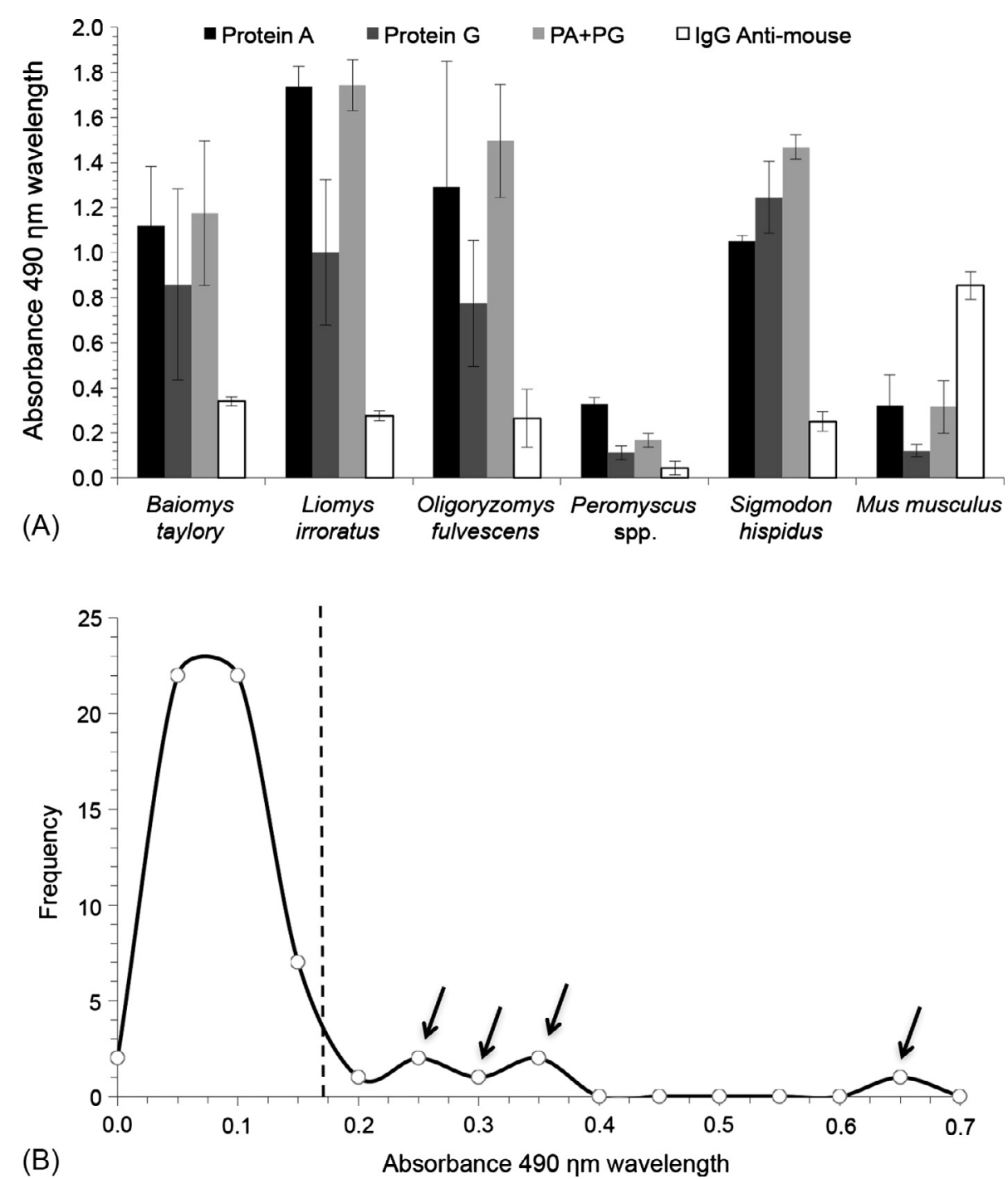

Figure 1. Immunoglobulin detection using three different conjugates and the mixture of Proteins A and G (PA + PG) by direct ELISA (A) and (B) frequency distribution of absorbance value in serum samples from four wild type rodents tested for anti-T. gondii antibodies by indirect ELISA. The dashed line is the calculated cut-off $(\mathrm{Ab}=0.17)$. Normal distribution of negative sera was determined by Shapiro-Wilk $(P=0.421)$ and Jarque-Bera $(P=0.486)$ statistics. Arrows indicate positive samples as determined by their position to the right of the cut-off.

prefers steppe, bushes, and scrubland, while $S$. hispidus mainly eats pastures $[4,10]$.

In western Mexico, De Villa et al. (2002) reported that rodents were the main component of the ocelot diet, most notably Liomys pictus, which represented $24.4 \%$ of consumed prey [9]. This is in agreement with a preliminary work in which T. gondii seroprevalence of $69 \%$ was found in ocelots of the same region studied herein [21]. Although the previous result may seem incongruent with the low prevalence found in rodents, it is possible that low prevalence in prey may lead to high transmission if they are the main meat source for predators. As a matter of fact, one bradyzoite is enough to experimentally infect cats and the burden found in the mouse (146 parasite/mg tissue) strongly suggests transmission in the zone [11]. Nevertheless, it would be important to determine the prevalence in Peromyscus spp. since it might provide further data on $T$. gondii infection pressure to ocelots in the zone. A useful conjugate technique for this species and analysis of a larger number of specimens of the other two species would be useful to gather more information regarding relative importance of several rodents on $T$. gondii transmission. The MAT technique could not be used in this study mainly because of importation regulation problems during the study and the low amount of serum available after ELISA was performed. This was unfortunate because it might have been a good technique to estimate the prevalence in Peromyscus spp.

The identification of new "atypical" $T$. gondii variants, which cause disease in humans, domestic, and wild animals, has triggered concern from both biological and public health perspectives, because spatial overlap of the wild and urban cycles may represent pressure of disease occurrence [22]. Therefore, it would be important to characterize $T$. gondii 
strains circulating in wild, rural, and urban regions, which are close together.

In conclusion, $T$. gondii is prevalent in at least two endemic rodent species ( $S$. hispidus and L. irroratus) of north-eastern Mexico where they are abundant and are preys of these felids. This report also expands the range of possibilities for serological diagnosis of $T$. gondii infection in some wild rodent species, using proteins $A$ and $G$ as conjugate in ELISA. So far, there are no reports of serological tests for detection of this protozoan in Peromyscus spp rodents; it would be interesting to test serum samples of this species with MAT. From the epidemiological viewpoint, it will be very interesting to analyze the genetic characteristics of strains of $T$. gondii that are circulating in wild animal populations and the degree to which sylvatic and domestic cycles are synonymous or distinct.

\section{Conflict of interest statement}

The authors declare that they have no conflict of interest.

\section{References}

1. Al-Adhami BH, Gadjahar AA. 2014. A new multi-host species indirect ELISA using protein $\mathrm{A} / \mathrm{G}$ conjugate for detection of anti-Toxoplasma gondii $\operatorname{IgG}$ antibodies with comparison to ELISA-IgG, agglutination assay and Western blot. Veterinary Parasitology, 200, 66-73.

2. Afonso E, Thulliez P, Gilot-Fromont E. 2006. Transmission of Toxoplasma gondii in an urban population of domestic cats (Felis catus). International Journal for Parasitology, 36, 1373-1382.

3. Afonso E, Thulliez P, Pontier D, Gilot-Fromont E. 2007. Toxoplasmosis in prey species and consequences for prevalence in feral cats: not all prey species are equal. Parasitology, 134, 1963-1971.

4. Cameron GN, Spencer SR. 1981. Sigmodon hispidus. Mammalian species, 158, 1-9.

5. Caso A. 1994. Home range and habitat use of three neotropical carnivores in northeast Mexico. Dissertation, Texas A\&M University-Kingsville, Kingsville, Texas.

6. Cedillo-Pelaez C, Rico-Torres CP, Salas-Garrido CG, Correa D. 2011. Acute toxoplasmosis in squirrel monkeys (Saimiri sciureus) in Mexico. Veterinary Parasitology, 180, 368-371.

7. Dabritz HA, Miller MA, Gardner IA, Packham AE, Atwill ER, Conrad PA. 2008. Risk factors for Toxoplasma gondii infection in wild rodents from central coastal California and a review of T. gondii prevalence in rodents. Journal of Parasitology, 94, 675-683.

8. De Thoisy B, Demar M, Aznar C, Carme B. 2003. Ecologic correlates of Toxoplasma gondii exposure in free-ranging neotropical mammals. Journal of Wildlife Diseases, 39, 456-459.

9. De Villa MA, Meyer EM, Lopez GCA. 2002. Ocelot (Leopardus pardalis) food habits on a tropical deciduous forest of Jalisco, Mexico. American Midland Naturalist, 148, 146-154.

10. Dowler RC, Genoways HH. 1978. Liomys irroratus. Mammalian species, 82, 1-6.
11. Dubey JP. 2001. Oocyst shedding by cats fed isolated bradyzoites and comparison of infectivity of bradyzoites of the VEG strain Toxoplasma gondii to cats and mice. Journal of Parasitology, 87, 215-219.

12. Dubey JP. 2010. Toxoplasmosis of animals and humans, 2nd edn. CRC Press: Boca Rica, Florida.

13. Dubey JP, Velmurugan GV, Alvarado-Esquivel C, AlvaradoEsquivel D, Rodriguez-Pena S, Martínez-Garcia S, GonzálezHerrera A, Ferreira LR, Kwok OC, Su C. 2009. Isolation of Toxoplasma gondii from animals in Durango, Mexico. Journal of Parasitology, 95, 319-322.

14. Gannon WL, Sikes RS, The Animal Care and Use Committee of the American Society of Mammalogists. 2007. Guidelines of the American Society Mammalogists for the Use of Wild Mammals in Research. Journal of Mammalogy, 348, 809-823.

15. Gilot-Fromont E, Lélu M, Dardé ML, Richomme C, Aubert D, Afonso E, Mercier A, Gotteland C, Villena I. 2012. The life cycle of Toxoplasma gondii in the natural environment, in Toxoplasmosis - Recent Advances, Djaković OD, Editor. p. 3-36, InTech Available from: http://www.intechopen.com/ books/toxoplasmosis-recent-advances/the-life-cycle-of-toxoplasma-gondii-in-the-natural-environment.

16. Instituto Nacional de Estadística y Geografía (INEGI. 2009. Prontuario de información geográfica municipal de los Estados Unidos Mexicanos, Soto La Marina, Tamaulipas. Clave geoestadística 28037. http://www3.inegi.org.mx/sistemas/mexicocifras/ datos-geograficos/28/28037.pdf [accessed 12 August 2014].

17. López-W R. 2003. Base de datos de los mamíferos de México depositados en colecciones de Estados Unidos y Canadá. Universidad Autónoma Metropolitana-Iztapalapa. http:// investigacion.izt.uam.mx/mamiferos/ [accessed 12 August 2014].

18. Mercier A, Garba M, Bonnabau H, Kane M, Rossi JP, Dardé ML, Dobigny G. 2013. Toxoplasmosis seroprevalence in urban rodents: a survey in Niamey, Niger. Memorias do Instituto Oswaldo Cruz, 108, 399-407.

19. Molsher R, Newsome A, Dickman C. 1999. Feeding ecology and population dynamics of the feral cat (Felis catus) in relation to the availability of prey in central-eastern New South Wales. Wildlife Research, 26, 593-607.

20. Murray LJ, Gardner LG. 1997. Leopardus pardalis. Mammalian species, 548, 1-10.

21. Rendón-Franco E, Caso-Aguilar A, Jiménez-Sánchez NG, Hernández-Jauregui DM, Sandoval-Sánchez AL, Zepeda-López HM. 2012. Prevalence of anti-Toxoplasma gondii antibody in freeranging ocelots (Leopardus pardalis) from Tamaulipas, Mexico. Journal of Wildlife Diseases, 48, 829-831.

22. Wendte JM, Gibson AK, Grigg ME. 2011. Population genetics of Toxoplasma gondii: new perspectives from parasite genotypes in wildlife. Veterinary Parasitology, 182, 96-111.

23. Wouda W, Dijkstra T, Kramer AM, van Maanen C, Brinkhof JM. 1999. Seroepidemiological evidence for a relationship between Neospora caninum infections in dogs and cattle. International Journal for Parasitology, 29, 1677-1682.

24. Xicoténcatl-García L. 2010. Estandarización y evaluación de un ELISA indirecto para el diagnóstico de infección por Toxoplasma gondii en mamíferos domésticos y su uso posterior en animales silvestres en cautiverio (Standardization and evaluation of an indirect ELISA to detect Toxoplasma gondii infection in domestic mammals and its further use in captive wild animal species). Dissertation, National Autonomous University of Mexico. 
Cite this article as: Rendón-Franco E, Xicoténcatl-García L, Rico-Torres CP, Muñoz-García CI, Caso-Aguilar A, Suzán G, Correa D \& Caballero-Ortega H: Toxoplasmosis seroprevalence in wild small rodents, potentially preys of ocelots in north-eastern Mexico. Parasite, 2014, 21, 57.

\section{OPARASTE}

Reviews, articles and short notes may be submitted. Fields include, but are not limited to: general, medical and veterinary parasitology; morphology, including ultrastructure; parasite systematics, including entomology, acarology, helminthology and protistology, and molecular analyses; molecular biology and biochemistry; immunology of parasitic diseases; host-parasite relationships; ecology and life history of parasites; epidemiology; therapeutics; new diagnostic tools.

All papers in Parasite are published in English. Manuscripts should have a broad interest and must not have been published or submitted elsewhere. No limit is imposed on the length of manuscripts.

Parasite (open-access) continues Parasite (print and online editions, 1994-2012) and Annales de Parasitologie Humaine et Comparée (1923-1993) and is the official journal of the Société Française de Parasitologie. 